\title{
THE ROLE OF MASS MEDIA IN ERADICATING CORRUPTION
}

\author{
By \\ YOHANES BERCHEMANS EBANG \\ Catholic University of Widya Mandiara - Kupang, Indonesia \\ e-mail: hansebang@yahoo.com
}

\author{
ARTICLE INFORMATION \\ Article history: \\ Received July 28, 2015 \\ Revised November 15, 2015 \\ Accepted May 15, 2016

\section{JEL Classifications} \\ H59
}

\section{Key Words:}

Mass media,

Corruption.

\section{DOI:}

10.21532/apfj.001.16.01.02.16

\begin{abstract}
So far, Indonesia has never been able to escape from the entanglement of corruption. This fact requires all elements of the nation to participate actively in combating this social scourge. Given that Indonesia is a democratic state, where the people are the holder of supreme power, the people have an important role in uncovering and combating the problem of corruption. One of the role and participation of the public is through the media. The reason is because the mass media can reach all levels of society. The mass media is a strategic tool that is able to sniff out and dismantle the rotten practices that start emerging or still veiled. The fact proves that in various places in Indonesia and abroad, corruption is always associated with the mass media.
\end{abstract}

\section{INTRODUCTION}

History shows that corrupt practices in Indonesia have taken place since the founding of this country or even in the early physical revolutionary period. According to Ajip Rosidi, it can be seen through the romances by Pramoedya Ananta Toer and Moktar Lubis where at that time there were some people who took personal advantage from the country's wealth in the midst of the struggle for Independence. Bung Hatta, one of the proclaimers of the Independence of Indonesia, said that corruption had been entrenched. ${ }^{1}$ At present, corruption still becomes hot topic and even the head line of almost all newspapers. Daily Kompas, for example, throughout the month of August 2012 was hardly ever absent to write the issue of corruption, even there were six special opinions reviewing

$1 \quad$ Ajip Rosidi, Korupsi Kebudayaan; (Jakarta, Pustaka Jaya 2006) p. $9-26$ 
the corruption. This indicates that such social catastrophe continues to thrive until this day. According to a survey in 2009 by the Political and Economic Risk Consultancy (PERC), an agency based in Hong Kong, Indonesia occupied the first position of the 14 most corrupt countries in the world. ${ }^{2}$

Seeing the situation and reality, many experts conclude that corruption is the biggest problem being faced by the nation and has tarnished the nation's image in the eyes of the world. Then there is a simple question: How and when will this social catastrophe stop? This question obviously challenges all elements of the nation. Scientists and experts are also challenged to demonstrate a variety of strategies and ways to help law enforcers to combat corruption. Jeremy Pope, in his book entitled "Strategi Memberantas Korupsi" (Combating Corruption Strategy), outlines 12 strategies or pillars to counteract corruption. ${ }^{3}$ For example, corruption can be eradicated by imposing the curriculum of anti-corruption in schools and colleges, ${ }^{4}$ as has been applied in certain universities, embarrassing the corruptors with social punishment, or impoverishing the corruptors, as written by Kacung Marijan and Sunario Basuki in the opinion column of daily Kompas. ${ }^{5}$ From the variety of solutions and strategies, the writer notices that to eradicate

2 Wijayanto and Ridwan Zacire (Edit.), Korupsi Mengkorupsi Indonesia, (Jakarta: Gramedia Pustaka Utama, 2009), p. XVII, XXV

3 Jeremi Pope, Strategi Memberantas Korupsi (Jakarta: Yayasan Obor, 2003), p.69, 89-282

4 Daily Kompas edition of Wednesday, August 7, 2012

5 Daily Kompas edition of Wednesday August 22, 2012, p. 6 corruption requires the active role of mass media, particularly newspapers. Then, what and how is the role of mass media? The question will be described in the content of this paper.

\section{FORMULATION OF THE PROBLEM}

Before discussing the matter further, the writer firstly would like to review the definition of corruption and to narrow the definition based on the context and purpose of writing this paper (wide and narrow definition of corruption). From the narrow definition of corruption, the writer emphasizes the impacts of corruption, especially on the wider community.

Seeing the large impact of corruption, the public should not keep silent. The public must play a role. Given that mass media is inseparable from the public (community) which can reach and is accessible to the public (all layers of society), it is the reason why media must have a role. To carry out this role, the media must be free and independent. The freedom and independence of the media can be seen through the news in sounding the truth and bad bureaucracy, as well as the institutions involved in corruption cases.

\section{III.DISSCUSSION}

\section{A. Definition of corruption}

Etymologically, the word corruption comes from the Latin word 'coruptio'. The word was later used as a vocabulary in several languages, for example, in English 'corruption', in French 'corruption' in Dutch 'corruptive' (kuruptie), and in Indonesian 'korupsi'. Literally, it means rottenness, badness, depravity, dishonesty, 
corruptible, immorality, perversion of sanctity. ${ }^{6}$ Desi Anwar, in her latest Complete Indonesian Dictionary, formulates that corruption is a foul deed, such as embezzlement, accepting bribes, and so forth. ${ }^{7}$

According to Law No. 20 of 2001 on Corruption Eradication in Chapter II, Article 2 and 3; Corruption is an unlawful act or acts to enrich himself or others, abusing authority, opportunity or means available to him because of the position held, corporate money that can be detrimental to corporate finance, state finances, or economy of the State. ${ }^{8}$ While other definitions which are widely used and referenced, including by the World Bank, corruption is "the abuse of public office for private gain" or formulated in Indonesian in the book entitled 'Korupsi Mengkorupsi Indonesia', corruption is the misuse of public office for private interests in ways that are contrary to the provisions of applicable law. Still from the same source, it is mentioned that corruption can occur if the following three things are met; first, someone has power including determining public policy and administering policies; second, the existence of economic benefits of the policy; third, the existing systems or policies open chances of violation. $^{9}$

6 Wijayanto and Ridwan Zacire (Edit.), Korupsi Mengkorupsi Indonesia, (Jakarta: Gramedia Pustaka Utama, 2009), p. 557

7 Desi Anwar. Kamus Lengkap Bahasa Indonesia Terbaru, (Surabaya: Amelia, 2003) p.

8 Hari Sasangka, Komentar Korupsi, Bandung: Mandar Maju, 2007

9 Wijayanto dan Ridwan Zacire (Edit.), Korupsi Mengkorupsi Indonesia, (Jakarta: Gramedia Pustaka Utama, 2009), p.6-8
From the definitions of corruption above, it can simply be summed up that corruption is as an attitude or action of misusing public authority, office and position either individually or in groups by embezzling and using corporate money or state money for the sake of personal interest that could harm corporate or state finances. This definition of corruption at a time narrows the understanding of corruption based on the context and purpose of writing this paper.

\section{B. The impact of corruption}

Corruption will have a negative impact on democratic countries and will continue to have a negative impact on human rights issues, living environment issues and all global aspects. $^{10}$

The quote above illustrates how fatal the impact of corruption, the social disease that has been entrenched. Corruption, in fact, has no impact on economic or financial matters but it comes in and hits all aspects of human life. A simple example of the living environment issues is the policy that benefits certain officers (diverting some funds into private pockets), in which, at a time, the policy is harmful to environments, having impacts on health and

Secaraumumtindakanilegalsepertipenggelapan uang, penyelundupan yang tidak melibatkan pejabat publik juga dapat dikategorikan sebagai korupsi karena merugikan keuangan dan perekonomiaan Negara Indonesia. Atau perbuatan- perbuatan yang dikategorikan dalam tindakan korupsi karya Hari Sasangka tercantum 29 daftar perbuatan, juga ke-29 hal yang sama dapat dibaca pada Lampiran I buku Korupsi Mengkoropsi Indonesia halaman 594599 yang mana juga diadopsi dari sumber yang sama.

10 Jeremi Pope, Strategi Memberantas Korupsi (Jakarta: Yayasan Obor, 2003), p. 551 
the oppression of indigenous people. ${ }^{11}$

Michael Johnson, as cited in the book entitled 'Korupsi Mengkorupsi Indonesia', mentions four issues that are so concerned that corruption becomes a problem that must be studied thoroughly from the political, economic and institutional aspects: first, the high cost due to corruption is found to inhibit the politic and economic developments; second, corruption causes systematic harmful effect; third, corruption is widespread in the economic field, especially in the interest of the State; fourth, corruption leads to or has an impact on unaccountable political monopoly practices. In addition to the points mentioned above, corruption also has negative effect on the six main subjects with the ranking of the most vulnerable and the biggest in percentage, namely: politic and public administration, history, law and education, economy, culture and business ethics. ${ }^{12}$

\section{Why mass media should play a role}

Harold Lasell, a prominent political expert, cited by Sri Nilawati and Ribut Susanto in their paper 'Media \& Transparansi', argues that the main function of mass media is: to

11 Wijayanto and Ridwan Zacire (Edit.), Korupsi Mengkorupsi Indonesia, (Jakarta: Gramedia Pustaka Utama, 2009), p. 263

Adalah sebuah contoh kasus pada satu bidang tetapi juga berdampak luas pada bidang-bidang yang lain, dan dapat ditambahkan misalnya aliran dana di bidang pendidikan, kesehan yang penggunaan dananya tidak maksimal, yang berdampak pada mutu proyek, bangunan, barang, atau sarana dan prasarana yang juga akan berdampak pada aspek pertumbuhan SDM para sasaran pendidikan dan masyarakat luas.

12 Ibid, p. 606-607 levy, to collect, to interpret, and to broadcast news. Besides having important role in reporting the news based on facts, media also has the potential to sensitize and encourage the public to change the mindset and way of life. In addition, mass media can be a facilitator that facilitates public dialogue or discussion between people and government. This could happen if the media owners are independent parties that always perform critical control and monitoring functions to the government. The free and independent mass media becomes the key actor in a democratic country when facing with the problem of corruption. ${ }^{13}$

From the definition of corruption, the impact, and the discourse of corruption that have become hot issues until today encourage all layers and elements of the nation to act. Given that our country is a democratic country, in which the people are the holder of the supreme power, the people also have an important role in uncovering and combating the problem of corruption. One of the roles and participations of the people is through the mass media, because mass media can reach and accessible to all levels of society. Mass media is a strategic tool that is able to sniff and uncover rotten practices that start emerging or still veiled. The fact proves that in various places in Indonesia and overseas, corruption cases are always associated with the mass media. Both of them are like two opposite correlation.

\section{Information is power. The greater} the number of people who have

\footnotetext{
13 Susan Rose - Ackerman, Korupsi Dan Pemerintahan, (Jakarta: Sinar Harapan, 2010) p. 228
} 
information, the more extensive the power sharing. Chance of getting information is a fundamental factor for the integrity of a state's systems. Without the opportunity, the democratic institutions will not run properly, and the citizens cannot exercise their expected rights and they do not even know that their rights have been violated. The primary tool for presenting information to the people is independent and free media. ${ }^{14}$

It cannot be denied that the role of mass media is extremely needed. Free and independent press is a public authority and power that should be free from the political influence, or free press. Mass media is present as a counter-power that is not only giving news but also fighting against and dismantling corruption.

\section{Independent mass media}

Karaniya Dharmasaputra in her paper entitled 'Media dan Foklor Korupsi', in the introduction, shebriefly presents herexperiences and observations as a senior journalist in which she is very keen to investigate and write cases of corruption. Dharmasaputra recognizes that independent media has a very important and strategic role in efforts to combat corruption. ${ }^{15}$ The role can be run properly if the mass media can perform the role and functions of its independence well. The independence of the mass media is actually an idea that journalists

14 Jeremi Pope, Strategi Memberantas Korupsi (Jakarta: Yayasan Obor, 2003), p. 220

15 Wijayanto and Ridwan Zacire (Edit.), Korupsi Mengkorupsi Indonesia, (Jakarta: Gramedia Pustaka Utama, 2009), p. 693 should be free from any forms of interference of other parties when running and practicing their profession. ${ }^{16}$ For example, a journalist who is covering the story about corruption, in conducting his journalistic activities should be free of the interests of the people or the objects being covered.

The rights of independent journalists sometimes cannot run properly when the government (corruptor) has a role and intervene in the internal affairs of the media. It is not only about the ownership of media, but also those who order ads or sponsors. If most sponsors or advertisements of a mass media are dominated by government, the independence of the media concerned is ultimately vague and even buried. On the other hand, media is expected to be independent in performing its functions of control and investigation. When the role of the media is missing, then there will not be the involvement of the media in enhancing the transparency in the administration of the state. ${ }^{17}$ Meanwhile, good governance requires transparency as one of the essences and other foundations in the form of freedom in gaining information.

\section{E. Mass Media Should be Free}

Free mass media is as important as an independent judiciary, as a twin power rivaling and suing corrupt practices. ${ }^{18}$ Dealing with the problem of corruption, media ownership, and

16 Jeremi Pope, Strategi Memberantas Korupsi (Jakarta: Yayasan Obor, 2003), p 223

17 Lukas Lawarso, Media Dan Transparansi, (Jakarta: SEAPA, 2004) hal.93

18 Jeremi Pope, Strategi Memberantas Korupsi (Jakarta: Yayasan Obor, 2003), hal 221 
the intervention of other parties (government) greatly affects the freedom of the mass media. In this case, the ownership of media means if the media concerned is owned by corrupt government, so the media will no longer free in presenting the news and in dismantling corruption that is ensnaring the government. Such cases are called power infidelity.

The level of freedom of the mass media can be measured through the achievement in carrying out its function as a public force in conducting effective supervision of the daily government's behavior. In such cases, journalists must be free of scandal or bad practices such as bribery.

\section{CONCLUSION}

Related to the issue of social life, in which the nation is increasingly entangled by corruption cases, it requires all elements of the nation to play their role in eradicating this social scourge. One of the subjects of this task is the community. The community can play an active role through media, considering that mass media serves as a means as well as a container for sharing. It cannot be denied that the role of the media is extremely needed. Free and independent press is a public power that should be free from political influence. Free press is a counter-power that does not only present the news but also fight against and dismantle corruption.

In this case, mass media is required to be bold and free without being influenced by corrupt rulers (government). The people, as the key actors, are also required to actively participate in media. The participation of the people can be in simple way that is by reporting cases of corruption and following the development of the corruption news by reading, watching and listening to the news broadcasted by the media.

\section{REFERENCES}

Ajip Rosidi, Korupsi Kebudayaan; (Jakarta, Pustaka Jaya 2006)

Desi Anwar. Kamus Lengkap Bahasa Indonesia Terbaru, (Surabaya: Amelia, 2003)

Hari Sasangka, Komentar Korupsi ( Bandung: Mandar Maju, 2007)

Harian Kompas edisi Rabu 7 Agustus 2012 , Rabu 22 Agustus 2012

Jeremi Pope, Strategi Memberantas Korupsi (Jakarta: Yayasan Obor, 2003)

Lukas Luwarso, Media dan Transparansi (Jakarta: SEAPA, 2004)

Susan Rose - Ackerman, Korupsi Dan Pemerintahan, (Jakarta: Sinar Harapan, 2010)

Wijayanto dan Ridwan Zacire (Edit.), Korupsi Mengkorupsi Indonesia, (Jakarta: Gramedia Pustaka Utama, 2009) 